\title{
Use of Bio-Modified Raw Materials of Plant And Animal Origin in Technology of Functional Foods
}

\author{
Kurchaeva Elena \\ Faculty of Veterenary Medicine \\ and Animal Husbandry Technology \\ Voronezh State Agrarian Univercity named after \\ Emperor Peter the Great \\ Voronezh, Russia \\ alena.kurchaeva@yandex.ru \\ Derkanosova Natalya \\ Faculty of Technology and Merchandizing \\ Voronezh State Agrarian Univercity named after \\ Emperor Peter the Great \\ Voronezh, Russia \\ kommerce05@1ist.ru
}

\author{
Maksimov Igor \\ Faculty of Technology and Merchandizing \\ Voronezh State Agrarian Univercity named after \\ Emperor Peter the Great \\ Voronezh, Russia \\ maximus880@mail.ru
}

\author{
Vostroilov Aleksander \\ Faculty of Veterinary Medicine \\ and Animal Husbandry Technology \\ Voronezh State Agrarian Univercity named after \\ Emperor Peter the Great \\ kaftchz@veterin.vsau.ru
}

\author{
Artemov Evgeny \\ Faculty of Veterenary Medicine \\ and Animal Husbandry Technology \\ Voronezh State Agrarian Univercity named after \\ Emperor Peter the Great \\ Voronezh, Russia \\ evgeartemov@yandex.ru
}

\begin{abstract}
Development of prescription solutions using plant additives based on the principles of combinatorics is promising in the food industry and is widely used. Studies of the health of the population of Russia, the structure of nutrition, the body's food substances, conducted by the Institute of nutrition of the Russian Academy of Sciences, have shown a serious deficiency of physiologically active ingredients in food, including meat-based. The most effective way from the technological viewpoint of solution of the problem of eliminating micronutrient deficiency in the diet is the development and creation of industrial production of enriched foods, with the addition of missing micronutrients in quantities corresponding to the physiological needs of a person.

We investigated a combined stuffing system based on semi fat pork, bio-modified lungs of cattle, rabbit minced meat of manual boning. We established the regularities of the influence of flour made from bio-modified seeds having mung's functional and technological properties of model minced meat using beef of the second rate, bio-modified lungs of cattle and rabbit meat of manual boning. The formula-component composition of sausage breads based on combined minced meat with the use of computer modeling methods is substantiated; the complex assessment of quality indicators is given. The developed recipe of sausage bread "Vitadar" is different from the control sample - sausage bread
\end{abstract}

"Zakaznoi" with a high mass fraction of protein - $18.5 \%$, carbohydrates $-10.2 \%$, including dietary fiber $-6.2 \%$. The yield of the finished product increased by $11 \%$ compared to the control sample.

Key words — rabbit meat, food combinatorics, sausage bread, functional and technological properties.

\section{INTRODUCTION}

At present, there is need to expand the diet of the population in order to balance it, which is achieved by applying the principles of food combinatorics based on the use of animal and vegetable protein in the production of meat products [3]. The source of vegetable protein may be the legume culture mung with a unique chemical composition, which is free of gluten and which is an acute problem for people suffering from wheat gluten intolerance $[9,10]$.

In the production of functional meat-based products as the main raw material with dietary properties, rabbit meat is promising. Among all products of animal origin, rabbit meat contains less cholesterol, minimal fat, and is high in protein. 
Rabbit meat is characterized by the following chemical composition, \%: moisture - 74-77\%, protein - 19-21\%, fat - 5$6 \%$ and minerals - 1-1.1\%. Rabbit meat proteins contain 19 amino acids, including essential ones. Particularly large contents in the rabbit is lysine, which amounts to $10.43 \%$, methionine $-2.37 \%$ and tryptophan $-1.55 \%$. Rabbit meat contains a rich mineral and vitamin composition: it contains a lot of iron (almost twice as much as pork), phosphorus $(220 \mathrm{mg}$ per $100 \mathrm{~g})$, magnesium ( $25 \mathrm{mg}$ per $100 \mathrm{~g}$ ) and cobalt, enough copper, potassium, manganese, fluorine, zinc. The sodium content is insignificant [11]. Rabbit meat is characterized by a rich vitamin composition, among which one may distinguish vitamin PP-nicotinamide, ascorbic acid, B6-pyridoxine, B12cobalamin, which makes the rabbit indispensable in the treatment-and-prophylactic food (with various diseases of the gastrointestinal tract, stomach, biliary tract, liver, allergies, hypertension).

Mass development of functional products will allow one to solve the problem of providing the population with valuable biologically active substances that will help to increase the resistance of the human body to adverse environmental conditions, improve the quality of life, reduce the risk of a number of diseases, and as a result - significantly improve the health of the Russians.

It should be noted that human health depends on the health system by only $8 \ldots 12 \%$, while the share of the impact on the health of socio-economic and human life, including nutrition, is $52 \ldots . .55 \%$.

The proportion of nutrition in the development of atherosclerosis and obesity is not less than $50 \ldots 75 \%$. More than half of cancers occur as a result of malnutrition. The diseases that are now common due to metabolic disorders also depend largely on nutrition.

The concern of the population about what they eat and what the consequences of the consumption of a particular food can lead to the production of food called "healthy food". "Healthy food" means the use of "functional foods" in the daily diet. Functional foods are any modified food product or food ingredient that can have a beneficial effect on human health in addition to the effects of traditional nutrients which they contain [8].

Solving the problem of providing all segments of the population with high-quality and affordable food, the scientists of the Russian Agricultural Academy, as well as Voronezh agricultural University, are conducting studies aimed at improving the quality and safety of agricultural raw materials and finished products, paying special attention to the scientific justification and practical use of the possibility of formation of the required quality characteristics of agricultural raw materials and the creation of balanced food products based on the principles of food combinatorics and resource saving [10, 11, $21]$.

The purpose of the work is to justify the use of bio-modified seeds of mung and the protein composite of cattle (lungs) in the formulation of emulsified meat product of high biological and nutritional value.

\section{OBJECTS AND METHODS OF RESEARCH}

The objects of the studies are the offal of the 2 nd category, beef of the 2 nd rate, biomodification chopped lung of cattle, minced rabbit meat of manual boning (MB). We used rabbits of Californian breed, grown in conditions of smallholders Semiluki district of Voronezh region, commercial cultures of microorganisms ("Bifidum № 791 BUG" bifidumbacterium.bifidum No. 791BAG, bifidumbacterium.bifidum 8-3 and bifidumbacterium.longum, "Bioantibut" - Str. lactis, Str. Diacetilactis, Str. Cremoris, Leuc. Citrovorum and" BACTOFERM F-SC-111 " - Lactobacillus curvatus HJ5 and Staphylococcus carnosus M III, as well as model minced meat and finished meat products. The flour from bio-modified mung seeds was used as a vegetable enriching component. Mung seeds were soaked at a temperature of $18^{\circ} \mathrm{C}$ for 18 hours with a humidity of 26-28\% and germinated for 4 days at a temperature of $13-16^{\circ} \mathrm{C}$ to a length of sprouts to $3-4$ $\mathrm{cm}$.

The pilot study was conducted in the conditions of the department of private animal science, center for collective use "Control and management of energy efficiency projects "VSUET". Chemical composition and quality assessment of raw materials and finished products were carried out by standard methods $[2,5]$.

Determination of the amino acid seeds of mung was carried out by high-performance liquid chromatography on the amino acid analyzer in accordance with the instructions to the device. The study of functional and technological properties of the meat product, the determination of moisture-binding capacity were carried out by pressing, moisture-holding capacity - with the help of milk fat meter. Fat-holding capacity was determined by the mass fraction of fat in minced meat before and after heat treatment, emulsifying ability and emulsion stability - by centrifugation. The organoleptic evaluation of meat products was carried out on a nine-point scale to establish the compliance of the quality indicators of the finished products with the requirements of normative and technical documentation [2].

\section{RESULTS AND THEIR DISCUSSION}

An important direction of the state policy in the field of healthy food is the introduction of food products with high nutritional value, obtained with the use of raw materials of the agro-industrial complex, containing functional nutrients in its composition. In this aspect, a special role is given to the use of both secondary meat raw materials used irrationally (byproducts obtained during the slaughter of farm animals) and meat resources with dietary properties, which primarily include rabbit meat. Analysis of the chemical composition of rabbit meat showed the predominance of proteins (up to $22.5-23.0 \%$ ) with a low fat content (up to 9.5-10.6\%) [17-20].

The little-used reserve of meat raw materials both in the Voronezh region and in adjacent areas where production of meat of cattle is concentrated is the products accompanying their slaughter. Slaughtering includes meat and fat, receives protein raw materials, such as collagen - containing byproducts, which is used irrationally, directed mainly to feed purposes due to the characteristics of their properties, in particular high strength characteristics, or are sold in the trading 
network in small quantities. Rational use of secondary raw materials of the meat industry can lead not only to significant saving of material resources and the creation of waste-free technologies, but also contribute to the improvement of the environment [13]. Category-II by-products are characterized by low values of functional and technological properties due to the high content of connective tissue and are not sufficiently used in the production of meat-based food.

By-products are unequal in their composition and nutritional value. The chemical composition of by-products is presented in table 1 . The amino acid composition of by-products is presented in table 2 .

TABLE I. CHEMICAL COMPOSITION OF BY-PRODUCTS

\begin{tabular}{|l|l|c|c|c|c|}
\hline \multirow{2}{*}{ By-products } & \multicolumn{2}{|l|}{$\begin{array}{l}\text { Composition, \% to the pulp } \\
\text { portion }\end{array}$} & \multicolumn{2}{|c|}{$\begin{array}{l}\text { Nitrogen in } \\
\text { incomplete proteins, \% } \\
\text { to total nitrogen }\end{array}$} \\
\cline { 2 - 6 } & Protein substances & Lipids & Water & Collagen & Elastin \\
\hline Heart & 15.2 & 3.0 & 79.0 & 15.2 & 0.6 \\
\hline Trip & 14.8 & 4.2 & 80.0 & 45.0 & 4.0 \\
\hline Lungs & 15.2 & 4.7 & 77.5 & 30.6 & 6.7 \\
\hline Udder & 12.3 & 13.7 & 72.6 & \multicolumn{2}{|c|}{53.0} \\
\hline
\end{tabular}

TABLE II. AMINO ACID COMPOSITION OF BY-PRODUCTS

\begin{tabular}{|c|c|c|}
\hline \multirow{2}{*}{ Amino acid } & \multicolumn{2}{|c|}{ Content, $\%$ to total protein } \\
\hline & Tripe beef & Lung \\
\hline \multicolumn{3}{|c|}{ Essential amino acids } \\
\hline Valine & 3.8 & 4.3 \\
\hline Isoleucine & 4.3 & 3.5 \\
\hline Leucine & 6.0 & 5.8 \\
\hline Lysine & 5.4 & 4.9 \\
\hline Methionine + cystine & 2.0 & 2.1 \\
\hline Threonine & 5.5 & 2.9 \\
\hline $\begin{array}{l}\text { Phenylalanin } \quad+ \\
\text { tyrosine }\end{array}$ & 4.9 & 4.5 \\
\hline Tryptophan & 0.6 & 0.8 \\
\hline The amount of & 32.5 & 28.8 \\
\hline
\end{tabular}

For the rational use of cattle lung, it is relevant to use the potential of microorganisms to improve the functionality of the selected resource and expand the prospects of its use.

For meat systems, model minced meat was used based on lung cattle with bacterial starter cultures of lactic acid bacteria of different species composition:

- $\quad$ sample without bacterial compositions - (control) chopped lung.

- sample No. 1- chopped lung with the addition of bacterial starter № 1 (bifidum № 791BAG bifidumbacterium.bifidum No. 791BAG, bifidumbacterium.bifidum 8-3 and bifidumbacterium.longum);

- $\quad$ sample No. 2 - chopped lung with the addition of bacterial starter cultures No. 2 ("Bioantibut" - Str. lactis, Str. Diacetilactis, Str. Cremoris, Leuc. Citrus);

- $\quad$ sample No. 3 - chopped lung with the addition of bacterial starter cultures No. 3 (combo starter ("Bioartist" + "Bifidum № 791BAG"+ "BACTOFERM
F-SC-111" (HJ5 Lactobacillus curvatus and Staphylococcus carnosus M III)).

Consortia of microorganisms obtained on the basis of lactic acid bacteria cultures were introduced at the rate of $0.5-5 \%$ to the mass of the main raw material. "BACTOFERM F-SC-111" was introduced directly into the model-minced meat.

The starter was introduced in an optimally selected experimental dosage, which was $5.0 \%$ to the mass of meat raw materials. In all MLK samples (modified lung cattle), there is a decrease in active acidity and a faster accumulation of amine nitrogen (for 8-10 hours of fermentation) compared to the control sample from 0.10 to $0.35 \mathrm{mg} \%$. Further increase in the mass fraction of the consortium of microorganisms is not expedient for both economic and technological reasons (there is an excessive accumulation of lactic acid and acidic taste). When using the joint cultivation of lactic acid bacteria, the optimal combination of "Bioantibut" + " Bifidum № 791BAG "+" BACTOFERM F-SC-111" in a ratio of $3: 1: 1$, the $\mathrm{pH}$ reduction occurs to values of 4.8-5.1 for $6-8$ hours with the accumulation of lactic acid - 132-140 mg\%.

The functional and technological properties of the obtained meat systems were investigated during salting (minced meat from lung cattle without processing and with processing by a consortium of microorganisms-CM): moisture-binding (MB), moisture-retaining capacity (MRC).

In the process of traditional salting, there is a smooth increase and over-time stabilization of the moisture-binding ability of the meat system. The use of a consortium of microorganisms showed that in the process of salting there is a slight (3-8\%) and stable increase in moisture binding capacity during the entire period of curing from 41.5 to $47.1 \%$ - without processing by a consortium of microorganisms, and from 41.3 to $62.8 \%$ - when processing selected by a consortium of microorganisms.

During traditional salting, the dynamics of the established regularities can be explained by the fact that during the initial stages of hydrolysis in the meat system, the formation of hydrolysis products of protein molecules occurs due to the proteolytic activity of enzymes secreted by the consortium of microorganisms, which leads to an increase in the number of easily accessible charged groups capable of holding water. During deeper hydrolysis, there is accumulation of oligopeptides and free amino acids, which are known to be incapable of effective binding of water $[12,15,16]$.

When it is salted with the addition of microorganisms, the change in the moisture-binding ability of minced meat is associated with an increased intensity of microorganisms on the connective proteins of the chopped meat raw materials, which causes the accumulation of a large number of easily accessible charged groups.

Studies have shown that during traditional salting, there is a sharp increase in water-holding capacity at the first stage of salting, and a decrease in water-holding capacity is further recorded with the final values when using a consortium of microorganisms for all types of model minced significantly higher than in the traditional salting without addition of a consortium of microorganisms. These results indicate the 
synergy (mutual strengthening) of the combination of cultures of microorganisms and salt in the process of salting and preparation of minced meat of light cattle without processing by a consortium of microorganisms - with an indicator of moisture binding capacity of $46.5 \%$, and for meat processed by a consortium of microorganisms - with an indicator of moisture binding capacity of $61.8 \%$ after 10 hours of aging.

The obtained protein composite based on minced meat from lung cattle was characterized by physical and chemical parameters presented in table 3 .

To enrich meat products with proteins, products of soy bean processing containing proteins in a concentrated form are traditionally used, but the climatic conditions of the Central black earth region do not allow obtaining the volumes of this culture necessary to obtain protein preparations [1].

TABLE III. PHYSICAL AND CHEMICAL PARAMETERS OF PROTEIN COMPOSITE BASED ON CATTLE UDDER

\begin{tabular}{|l|c|c|}
\hline \multicolumn{1}{|c|}{ Indicator } & $\begin{array}{c}\text { Minced lung before } \\
\text { treatment with } \\
\text { microorganisms }\end{array}$ & $\begin{array}{c}\text { Minced lung after } \\
\text { treatment with } \\
\text { microorganisms }\end{array}$ \\
\hline \multicolumn{3}{|c|}{ Mass fraction, \%: } \\
\hline moisture & 56.00 & 67.80 \\
\hline fat & 17.70 & 14.20 \\
\hline protein & 12.90 & 14.20 \\
\hline ash & 0.80 & 0.64 \\
\hline pH & 5.80 & 5.00 \\
\hline
\end{tabular}

In this connection, there is a need to search for alternative sources of plant protein with sufficiently high functional and technological properties and different sustainable yield and unpretentiousness to soils. These conditions are satisfied by mung bean culture. Bean seeds of mung bean culture, used to produce a bio-modified form, contain a large amount of protein $-24 \%$, fat $1,4 \%, 3,5 \%$ ash, carbohydrates $58,5 \%$, including $8,2 \%$ fiber. The protein digestion rate is $86 \%$. Mung seeds do not have spare nutrient tissue (endosperm), so nutrients such as proteins, starch and lipids required for germination are deposited in their cotyledons and germ $[4,6,7]$. Bioactivation of mung seeds leads to an increase in their biological value due to the balance of the total composition of amino acids during the growth of the share of the most important in human nutrition (table 4). The biological value of bio-modified seeds of mung was $60 \%$, and native seeds of mung $-51 \%$.

To obtain combined meat systems, flour obtained from biomodified by germination of mung seeds was used in the work. To obtain flour, sprouted and dried seeds were ground on a colloidal mill. The resulting flour was sieved through a sieve with a hole diameter of $100 \mu \mathrm{m}$. Flour from the seeds of mung has a cream color with a greenish tint. According to the chemical composition the flour from bio-modified seeds, mung contains all the necessary macronutrients, mass $\%$ : water -12.0 , protein -25.0 , fat -0.7 , carbohydrates -58.5 , including fiber 8.2, ash -3.8 .
TABLE IV. AMINO ACID COMPOSITION OF THE SEEDS BEFORE AND AFTER GERMINATION (G/100G OF PROTEIN)

\begin{tabular}{|c|c|c|}
\hline Amino acid & $\begin{array}{r}\text { Control test - } \\
\text { native seeds }\end{array}$ & $\begin{array}{l}\text { Experimental } \\
\text { sprouted seeds }\end{array}$ \\
\hline \multicolumn{3}{|c|}{ Essential: } \\
\hline Valine & 7.10 & 7.90 \\
\hline Isoleucine & 4.40 & 5.30 \\
\hline Leucine of & 6.00 & 9.85 \\
\hline Lysine & 7.20 & 9.71 \\
\hline Methionine + cystine & 1.80 & 2.44 \\
\hline Threonine & 6.25 & 6.78 \\
\hline Tryptophan & 0.76 & 1.17 \\
\hline Phenylalanine + tyrosine & 12.2 & 14.86 \\
\hline $\mathrm{BV}, \%$ & 51.00 & 60.00 \\
\hline
\end{tabular}

The ratio of meat raw materials was chosen empirically from the study of functional and technological properties of meat systems (table 5).

TABLE V. FUNCTIONAL AND TECHNOLOGICAL PROPERTIES OF MODEL MINCED MEAT

\begin{tabular}{|l|c|c|c|c|c|c|}
\hline \multirow{2}{*}{ Indicator } & \multicolumn{6}{|c|}{$\begin{array}{c}\text { Ratio of raw meat (beef grade 2: minced cattle lung: } \\
\text { minced meat of rabbit of hand boning) }\end{array}$} \\
\cline { 2 - 7 } & $\mathbf{1 : 0 , 5 : 1}$ & $\mathbf{1 : 1 : 0 , 5}$ & $\mathbf{1 : 1 : 1}$ & $\mathbf{1 : 1 : 1 , 5}$ & $\mathbf{1 : 1 : 2}$ & $\mathbf{1 : 2 : 1}$ \\
\hline $\mathrm{MBC}, \%$ & 67.1 & 66.2 & 69.2 & 70.5 & 74.4 & 71.8 \\
\hline $\mathrm{MHC}, \%$ & 58.9 & 54.7 & 60.4 & 61.3 & 68.4 & 64.5 \\
\hline $\mathrm{JHC}, \%$ & 61.2 & 57.3 & 58.6 & 64.7 & 66.5 & 63.9 \\
\hline
\end{tabular}

Hydrated flour from the mung seeds was introduced into model minced meat (minced beef based on 2 varieties and biomodified lung cattle, and rabbit meat of manual deboning in the ratio of $1: 1: 2$ ) in the amount of $0-15 \%$ during hydration in the ratio of $1: 1-1: 4$. An empirically selected degree of hydration is 1: 3 , because further dilution with water leads to a decrease in functional and technological indicators. Hydration was performed for 45 minutes. The maximum value of functional and technological results have been obtained in replacement of meat raw materials in the amount of $12 \%$ and was: $\mathrm{MBC}-$ $78,4 \%$, the $\mathrm{MHC}$ and $71.6 \%$ and $\mathrm{JHC}-65,2 \%$.

The increase in the amount of water introduced leads to a slight decrease in moisture binding capacity. The growth of moisture-binding capacity in model minced meat with the addition of a vegetable additive is associated with an increase in the composition of the share of high-molecular compounds capable of swelling, besides binding and retention of moisture in the meat occurs $[1,11,14]$. The fat-holding capacity of model minced meat with the addition of flour from the seeds of mung at any hydromodule is higher than the fat retention by minced meat, which does not contain vegetable ingredients in its composition. The maximum value of the fat-holding capacity takes $12 \%$ replacement of the main raw material and the degree of hydration equal to $1: 3$. 
TABLE VI. ORGANOLEPTIC INDICATORS OF SAUSAGE BREAD SAMPLES

\begin{tabular}{|c|c|c|}
\hline \multirow{2}{*}{ Indicator } & \multicolumn{2}{|c|}{ Characteristics } \\
\cline { 2 - 3 } & $\begin{array}{c}\text { «Zakaznoi» } \\
\text { (control sample) }\end{array}$ & $\begin{array}{c}\text { «Vitadur» } \\
\text { (experimental sample) }\end{array}$ \\
\hline The appearance & \multicolumn{2}{|c|}{$\begin{array}{c}\text { Loaves with a clean, smooth, dry and evenly } \\
\text { toasted surface }\end{array}$} \\
\hline Appearance on the cut & $\begin{array}{c}\text { Pink, or light pink, evenly mixed and contains } \\
\text { pieces of fat the size of 8 - 12 mm }\end{array}$ \\
\hline Consistency & \multicolumn{2}{|c|}{ Elastic } \\
\hline The smell and taste & $\begin{array}{c}\text { Peculiar to this type of product, with the aroma of } \\
\text { spices, without foreign flavors and smells }\end{array}$ \\
\hline Output, \% & 106.00 & 112.00 \\
\hline
\end{tabular}

The experimental data formed the basis for the creation of recipes of sausage bread "Vitadar" in comparison with the control sample "Zakaznoi". Analysis of organoleptic (table 6) and physical and chemical parameters of the experimental and control samples of sausages (table 7) showed that the developed product has a high protein mass fraction $-18.5 \%$, dietary fiber $-6.2 \%$, lower fat mass fraction $-27.8 \%$ compared to the control sample $-37.0 \%$. The amino acid composition of sausages is presented in table 8 .

TABLE VII. PHYSICAL AND CHEMICAL PARAMETERS OF SAUSAGE BREAD SAMPLES

\begin{tabular}{|l|c|c|}
\hline \multirow{2}{*}{ Indicator } & \multicolumn{2}{|c|}{ Characteristics } \\
\cline { 2 - 3 } & $\begin{array}{c}\text { «Vitadur» } \\
\text { (Zakaznoi» } \\
\text { (experimental } \\
\text { sample) }\end{array}$ \\
\hline Mass fraction of fat, \% & 37.0 & 27.8 \\
\hline Mass fraction of protein, \% & 10.8 & 18.5 \\
\hline Mass fraction of moisture, \% & 49.0 & 45.8 \\
\hline $\begin{array}{l}\text { Mass fraction of } \\
\text { carbohydrates, \%; } \\
\text { including dietary fiber, \% }\end{array}$ & 3.2 & 7.9 \\
\hline Mass fraction of table salt, \% & - & 6.2 \\
\hline $\begin{array}{l}\text { Mass fraction of sodium } \\
\text { nitrite, \% }\end{array}$ & 2.5 & 2.3 \\
\hline
\end{tabular}

TABLE VIII. AMINO ACID COMPOSITION OF SAUSAGES

\begin{tabular}{|c|c|c|c|c|c|}
\hline \multirow{3}{*}{$\begin{array}{l}\text { Amino } \\
\text { Acids }\end{array}$} & \multirow{3}{*}{\begin{tabular}{|l|} 
Standard \\
FAO/ \\
WHO, \\
g / 100 g \\
protein \\
$(2011)$ \\
\end{tabular}} & \multicolumn{4}{|c|}{ Product } \\
\hline & & \multicolumn{2}{|c|}{$\begin{array}{c}\text { "Zakaznoi» } \\
\text { (control sample) }\end{array}$} & \multicolumn{2}{|c|}{$\begin{array}{c}\text { "Vitadur" } \\
\text { (experimental sample) }\end{array}$} \\
\hline & & $\begin{array}{l}\mathrm{g} / 100 \mathrm{~g} \\
\text { protein }\end{array}$ & $\begin{array}{c}\text { Amino acid } \\
\text { score, } \%\end{array}$ & $\begin{array}{l}g / 100 g \\
\text { protein }\end{array}$ & $\begin{array}{c}\text { Amino acid } \\
\text { score, } \%\end{array}$ \\
\hline Isoleucine & 3.0 & 4.45 & 148.3 & 4.65 & 155.0 \\
\hline Leucine & 6.1 & 7.21 & 118.9 & 7.32 & 120.0 \\
\hline Lysine & 4.8 & 6.59 & 137.3 & 6.92 & 144.1 \\
\hline $\begin{array}{c}\text { Methionine }+ \\
\text { cystine }\end{array}$ & 2.3 & 3.43 & 149.1 & 3.88 & 168.7 \\
\hline $\begin{array}{l}\text { Phenylalanine } \\
+ \text { tyrosine }\end{array}$ & 4.1 & 4.72 & 118.0 & 5.25 & 128.0 \\
\hline Threonine & 2.5 & 3.22 & 128.8 & 3.34 & 133.6 \\
\hline Tryptophan & 6.6 & 4.72 & 71.5 & 5.80 & 87.8 \\
\hline Valine & 4.0 & 4.46 & 111.5 & $5 ., 48$ & 137.0 \\
\hline Histidine & 1.6 & 2.32 & 145.0 & 2.48 & 155.0 \\
\hline \multicolumn{2}{|l|}{$\mathrm{BV}, \%$} & \multicolumn{2}{|c|}{74.35} & \multicolumn{2}{|c|}{76.74} \\
\hline
\end{tabular}

It should be noted that there is increase in the developed product of the essential amino acids lysine and tryptophan involved in the formation of cell proteins, bone tissue, and serotonin in the human body.
The developed product is balanced in the amino acid composition (table 8), which determines its high nutritional value.

The obtained results positively estimate prospects of use of biomodificated seeds mung and protein composite based on minced cattle lung in composition of minced meat for sausage bread.

\section{CONCLUSIONS}

The possibility of using seeds of mung bean in the composition of minced meat loaves to make the product of functional orientation has been proved. Compared with the control sample of sausage bread, the yield of finished products increased from 106 to $112 \%$, the fat content decreased (from $37.0 \%$ to $27.8 \%$ ); besides the mass fraction of proteins increased (from $10.8 \%$ to $18.8 \%$ ).

\section{References}

[1] L. V. Antipova, A. A. Mishchenko, "Development of meat pates of high nutritional and biological value with the use of germinated lentils grain,' Bulletin of VSUIT, №. 4., pp. 115-120, 2016. doi: 10.20914/2310-12022016-4-115-120.

[2] L. V. Antipova, I. A. Glotova, I. A. Rogov, "Methods of use of meat and meat products," M.: KolosS, 2004, 576 p.

[3] L. V. Antipova, "Assessment of the potential sources of vegetable proteins for food production,” Food industry, №8, pp. 10-12, 2013.

[4] L. V. Antipova, I. N. Tolpygin, L. E. Martemianova "Texturate of vegetable proteins for food production,” Food industry. №. 2, pp. 20-23, 2014

[5] A. D. Dzhamakeeva "UV/VIS spectroscopy - perspectives of application of the method to studies of the value of plant materials and meat products," News of the Kyrgyz state technical University. I. Razzakova. Vol. 36, № 3, pp. 247-251, 2016.

[6] M. I. Ivanova, A. I. Kashleva, A. F. Razin "Sprouts-functional organic products (review)," Bulletin of the Mari state University. Series, Agricultural Sciences. Economic Sciences, № 7, pp. 19-29, 2016.

[7] S. A. Kazimov Prudnikova T. N. "Influence of germination on the amino acid composition of mung beans," News Of Universities. Food technology, 2012, № 5-6, pp. 25-26.

[8] D. L. Klabukova, S. V. Kolotvin, E. I. Titov, N. G. Mashentseva "Study of the effect of the composition of starter cultures on cholesterol in fermented meat products," Nutrition Issues, vol. 86, № 5, pp. 82-90, 2017 , doi: 10.24411/0042-8833-2017-00080.

[9] O. V. Klepikov, R. O. Hatuev, A.V. Istomin, L. A. Rumyantseva "Regional characteristics of the nutrition and the health risks associated with chemical contamination of food products," Hygiene and sanitation. 95 (11), pp. 1086-1091, 2016; DOI: http://dx.doi.org/10.18821/00169900-2016-95-11-1086-1091.

[10] A. B. Kravchuk "The influence of flour from bean seeds on the quality of sausage bread," in the collection: Modern trends in public catering and services interuniversity student scientific and practical conference, pp. 37 43, 2017.

[11] E. E. Kurchaeva, A. O. Ryazantseva, T. N. Tertychna "Development of meat products using complexes based on transferase preparations and plant protein,” Eurasian Union of scientists, №1-2 (22), pp. 73-76, 2016.

[12] S. P. Merenkova, A. A. Lukin, I. V. Zakharov "Biotechnological methods of stabilization of functional properties of meat systems," Commodity science of food products, № 10,pp. 19-24, 2015.

[13] D. V. Popkova, O. N. Anokhina "Development of meat bread recipe with vegetable ingredient," Proc. of the III international scientific and technical conference: materials November 2016, pp. 381-387 [Food security: scientific, personnel and information support-2016, Voronezh, 2016].

[14] A. G. Khramtsov, S. A. Ryabtsev, R. O. Budkevich, V. R. Ahmedov, A. B. Rodnaya, E. V. Marusina "Prebiotics as functional food ingredients: terminology, selection criteria and comparative evaluation, 
classification," Nutrition Issues, vol. 87, pp. 5-17, 2018, doi:10.24411/0042-8833-2018-10001.

[15] O. V. Zinina, M. B. Rebezov "Biotechnological Processing of Collagen Containing By-products of Bovine Animals," Research Journal of Pharmaceutical, Biological and Chemical Sciences, vol. 7, pp.1530-1534, Published: JAN-FEB 2016.

[16] J. B. Eun, J. H. Shon, J. H. Eo, et al. "Food hydrocolloids: characteristics, properties and structures," Hollingworth, C. S., ed.; Nova Science Pub Inc; UK ed. edition, pp.1-39, 2010.

[17] O. V. Pavlova "Meat and offal of rabbits in the technology of functional products for pregnant and lactating women," In the world of scientific discoveries, № 4-14, pp. 31-32, 2010.
[18] D. R. Khismatullin "Rabbit meat in human nutrition," New science: Current state and ways of development, № 5-2,pp. 222-225, 2016.

[19] Yu. A. Kalugin, N. Ah. Balakirev Fedorova O. I. "Rabbit meat as a dietary product,” Meat sphere, № 6, pp. 56-57, 2016.

[20] V. G.Popov, O. S. Fedorova, S. A. Belkina "Improvement of production technology of specialized products from rabbit meat," Polzun Herald. Vol.1, № 3, pp. 37-42, 2017.

[21] A. B. Lisitsyn, A.V. Ustinova, N. Ah. Gorbunova "The role of agronomy in providing the population of Russia with functional and dietary products,” All about meat, № 1, pp. 34-37, 2007. 